\title{
REACTION AND CONFERENCE SUMMARY
}

\author{
Martha Crago \\ President, Canadian Association of Graduate Studies and \\ Dean of Graduate and Postdoctoral Studies, McGill University
}

One of the keystones of this conference came from the man to whom I will refer to as our "elder"-Richard Schiefelbusch. At one point, he said quite simply "I think we have to go a little further." Indeed, this conference has been about moving our graduate studies and research enterprise a little further and I think it did much to move our thoughts further along.

In our hands we hold a great responsibility. During the conference Ellen Weissinger told me that when professors are tenured at her university, the provost tells them: "Our university is committing to you for life and we think so highly of you that we are committing generations of students to you." In Canada and the United States, graduate deans and vice presidents of research are responsible for close to 2 million graduate students and the scientific and scholarly futures of our two nations. This is a daunting responsibility. Robert Barnhill reminded us that our role is to see to the mentorship of those 2 million students, assuming the role of Odysseus' trusted counselor, under whose disguise Athena became the guardian and teacher of Telemachus. Debra Stewart likened us to Janus, the two faced god, simultaneously protecting those we are responsible for as well as searching out opportunities for them. It is our responsibility to help our graduate students attain a range of what John Colombo called "competencies," or as Mabel Rice put it: "Our goal is to create effective researchers who will help us acquire new knowledge." This is a sizable goal by any measure. It is a goal that will take not only us, but also our nations and society in general, a little further.

In moving forward, we need to understand ourselves better. We need to collect the same high quality data and analyze it, as we would do in our own disciplinary research endeavors. Facts can be transformative and we can capture our transformations in facts. Robert Barnhill showed us growth and investment charts that capture the recent transformations in research at KU. Comparative data helps to awaken us to our own local realities. I talked about the transformative effect of showing cross-university student retention data to the faculty at McGill University. However, both Debra Stewart and I acknowledged that it is not easy to get the facts straight. It is difficult to agree on definitions and taxonomies, and this difficulty will only increase as the nature of our graduate programs evolve beyond the classical disciplines with their well understood nomenclature.

Increasing importance is being given to multidisciplinary programs. The ability to educate our students to work and do research at the interface of 
disciplines certainly has the potential to enrich our knowledge. But it will be necessary as we move forward to make sure that multidisciplinarity is not simply a buzzword or a popular educational fad. We need to ask ourselves whether such programs are for all fields or for all students. It will be important to determine how to implement these programs in our universities in ways that are highly flexible and adaptive and in ways that avoid turf wars between departments and deans. Every institution has a different matrix of governance and it will be up to each institution to determine what arrangement for these programs best fits its own particular configuration.

I have an Inuit friend who lives in the far north of Canada. She once said to me that for her, television was like a periscope; it helped her to see what we, the other North Americans, are up to. This conference has provided me with a kind of periscope onto the graduate studies and research situation of the United States. I find it unusual to be looking across the border and finding that my American colleagues are going through difficult economic times. Such difficult times are a phenomenon that many Canadian academics thought was reserved only for our institutions. As an American Canadian I find myself empathetic to your situation. Straddling the borders as I do has perhaps given me an insideroutsider perspective from which to comment on what I see and hear about higher education in the United States at this time.

Once again, Richard Shiefelbusch summed it up nicely when he said, "We are in a bit of a crisis." In Canada, we are just emerging from a period of very deep budget cuts in our universities. We need to ask ourselves how ordinary people make it through hard times. How do they effectively deal when there is less to go around? Unless they are in denial or blindly optimistic, people in a time of need do not usually carry on as though nothing has happened. Instead, they share what they have with each other. They become more collaborative and they have to make choices. Universities need to be strategic in difficult economic times. They need to leverage funds and to become enterprising. We have heard interesting examples of such initiatives at his conference. We have spoken of initiatives such as partnering with the private sector, of marketing goods produced on our campuses, of encouraging granting agencies to increase funding to graduate students, and using laboratory space in the private sector for graduate students. People can manage amazingly well with relatively little. Perhaps, it is the Scottish heritage of my university that makes us work so hard on leveraging external funds. One small example of this is how we decided to assign operating funds in the form of fellowships to graduate students. Our operating funds are allocated to programs that have already been successful in attracting external fellowship money for their students. It is somewhat like a card game that my children play in which the rich get richer. This allocation formula serves as a reminder to the community that we must leverage external money and that university funds will be allocated to meritorious programs. 
Yet, being in difficult times also has very real dangers associated with it. It can push people into positions where they become desperate. This, in turn, can lead to regrettable partnerships and behavior. Richard Schiefelbusch told some of us that in his career, he had certain values that he felt it was important to uphold. The questions universities need to ask include: How far out on the edge can we go? What are our fundamental values? What will we uphold in our universities no matter what happens? I once arranged for Graham Bell, one of our preeminent scientists at McGill, to talk to a group of our top graduate students at McGill. He told the group about how some of the most important discoveries in biology have happened by accident in university laboratories where scientists were playfully experimenting. It is important to preserve the university as a place where such playfulness and free ranging thought can continue to exist. When research is only goal oriented, we are likely to lose something. Trying the ridiculous sometimes leads to finding the miraculous. One of the fundamental values of the university is that it is a protected environment in which our scientists and scholars have the freedom to think in unfettered ways. Kim Wilcox said it well when he told us that partnering with others is a question of balance.

We also discussed the societal situation of universities at this conference, asking ourselves, among other things, how we can change people's perceptions of graduate studies and research. Suzanne Ortega reminded us that universities cannot change in a vacuum, divorced from change in the society around them. Changing societal attitudes toward science and scholarship is important to the future of both research and graduate studies. I learned recently that $70 \%$ of Americans do not understand basic science. A recent survey reported that when Canadians, Americans and Europeans were asked if ordinary tomatoes had genes or if only genetically modified tomatoes had genes, the vast majority responded that ordinary tomatoes did not have genes. Diandre Leslie-Pelecky described for us a fine example of how she, as a physicist, had joined forces with a professor in education to change the attitudes that children in Kindergarten through 12th grade had about science and about pursuing scientific careers. The children were startled to learn that scientists could be pretty and could talk in ways that they understood. What and how we communicate to the public is clearly as important as what we communicate to our colleagues in scientific meetings. Our students, researchers and university administrators need to develop the kind of skills that will allow them to communicate about their work to a wider range of people. In this way more people can appreciate the work of scientists and scholars and more children will want to become them. An excellent initiative that I have heard about is the Wellcome Trust in the United Kingdom, which offers fellowships to students who agree that during their studies they will communicate about science to people of all ages from many walks of life.

The most painful part of what we have heard at this conference was what Debra Stewart and Diana Carlin conveyed to us about another important societal issue, namely that of international students in our universities. Once again there 
are questions that need to be asked. What did we think we were doing when we made it a virtue to attract international graduate students to our institutions? Were we only after their tuition fees? Were we after manpower for our laboratories? What is at risk if the fate of international students in American universities is endangered? I think that originally we may have begun encouraging international students to come to our universities as a sort of colonialism. Yet, in part, our aim was to educate them so that they might return to their home countries and build their own research and higher education networks. If that is true, then it should be a cause of joy rather than jealousy that graduate education in other countries is now a success. I think that Cambridge University, for example, should be proud of the fact that they accepted a young American man from a poor background and gave him a world class education so that he could return to the United States and become a leading figure in research and higher education in his own country. This young man was my father, and his graduate studies as an international student brought back enormous benefits to the people in the United States, not only to my own life but also to generations of university students in this country. Education is a kind of spark that we pass on to others. American universities have lit that spark for students from other countries in a remarkable way for the last 50 or more years. Will the present political situation extinguish it?

Why should we go on educating international students today? For one thing, they provide us with diversity, the kind that the Supreme Court decision about the University of Michigan is trying to defend, just at a time when we need it most. I have often wondered if we make the most of the diversity that international students bring to our campuses. Do we explore their lives and cultures and learn from them? Or, do we just try to convert them into fans for our sporting teams and expect them to learn about our way of life. One of our challenges is to figure out how we let the international students who are in our universities educate our North American students.

Let me give you an example from my university of another important aspect of educating international students. At McGill, we educate students from everywhere in the world. I consider this to be a great asset in a time when the people of the world lack understanding of each other. But I would like to explain two particular programs to you. For many years at McGill, we have had an Institute of Islamic Studies. About 10 years ago we received funding from the Canadian International Development Agency to bring Master's and doctoral students to McGill to study Islamic thought. This is a partnered program with two religiously based universities that are primarily responsible for educating the teachers who will teach in the Madrasas of Indonesia. After receiving their graduate degrees from McGill, the students in the program are slated to return to Indonesia and become professors and administrators of the partner universities. Before I knew much about this program, I was sent to Ottawa to persuade the government agency to continue its funding. I had only a short time to read the background documents and decide what I should say about the importance of 
investing in Indonesian students at a time when Indonesia was no longer considered a developing country. While reading my documents, I was astounded to learn how many Muslim people live in Indonesia. This made me question why Muslim students from Islamic Institutions would come to McGill for a program in Islamic studies. However, the partnered funding proposal that I was reading made the case that at McGill's Institute the students could learn what was referred to as "rational" Islamic thought. The concept was that through educating the educators of the teachers of the Madrasas this form of religious thought would trickle down to millions of people in Indonesia. Reflecting on this, it became clear what case I should be making to the federal funding agency. I realized that the political consequences of these students' graduate studies had the potential to be extremely significant to the world. This episode occurred in the year 2000 when I did not have any idea of what world events would be scarcely one year later. On the train ride back to Montreal, I talked with one of the Indonesian university's officials. He had received his Ph.D. from the University of California-Los Angeles in Islamic Studies. He asked me what the funding agency was considering as they evaluated the proposal. So I asked him in return if he could explain to me what was different about the education he had received in Indonesia and the one he had received at UCLA. He told me that in Indonesia he was never asked what the Koran meant. Instead he memorized it or recited it but he was never taught to interpret it. From this conversation, I realized how dramatic a difference an education at our institutions could make. It can serve a crucial political and humanizing role. At McGill we also have a Middle East Peace Building Program. This brings students from Palestine, Jordan and Israel together on our campus to obtain a Master's of Social Work. The students do their professional practice placements in community centers in the border areas of their home countries. Their time at McGill provides them with a safe haven in which they can explore their commonalities and differences and get to know each other as human beings, not only as political foes.

Our universities need to think very seriously about the particular role that they can play in the interest of global well-being. Developing our research capacity in the sciences that are associated with security is important, but $9 / 11$ was not due to a failure of science and technology. Rather, it was a failure to understand political, social and cultural forces. Higher education is an agent of change that develops human capacity, knowledge, and understanding. Above all, we must remember, as Debra Stewart pointed out, that education has always been a powerful weapon in times of uncertainty.

It has been a pleasure to have this opportunity to grow a little further in my own thoughts with you. 